\title{
Rat pancreatic level of cystathionine $\gamma$-lyase is regulated by glucose level via specificity protein 1 (SP1) phosphorylation
}

\author{
L. Zhang $\cdot$ G. Yang $\cdot$ G. Tang $\cdot$ L. Wu $\cdot$ R. Wang
}

Received: 26 November 2010 /Accepted: 19 April 2011 /Published online: 27 May 2011

(C) Springer-Verlag 2011

\begin{abstract}
Aims/hypothesis Cystathionine $\gamma$-lyase (CSE) catalyses the endogenous production of hydrogen sulphide $\left(\mathrm{H}_{2} \mathrm{~S}\right)$ in pancreatic beta cells, and $\mathrm{H}_{2} \mathrm{~S}$ has been shown to inhibit insulin release from these cells. As altered pancreatic $\mathrm{H}_{2} \mathrm{~S}$ production modulated by glucose has been previously shown, we hypothesised that the Cse gene could be regulated by glucose level in insulin-secreting cells.

Methods The effects of glucose on CSE protein level and mRNA level were analysed in INS-1E cells. Glucose effect on Cse promoter activity was tested by constructing a proximal $C s e$ promoter vector including specificity protein 1 (Sp1) consensus sequence.

Results High glucose $(20 \mathrm{mmol} / \mathrm{l})$ inhibited $\mathrm{H}_{2} \mathrm{~S}$ production in INS-1E cells and freshly isolated rat pancreatic islets. Cse mRNA expression, CSE activity and protein abundance were also profoundly reduced by high glucose. The involvement of SP1 in basal and high-glucose-regulated CSE production was demonstrated. Spl-knockdown abolished a large portion of CSE production at basal glucose. Phosphorylation of SP1 stimulated by high glucose was inhibited by p38 mitogenactivated protein kinase (MAPK) inhibitors SB203580 and SB202190. After blocking p38 MAPK phosphorylation, the
\end{abstract}

L. Zhang $\cdot$ R. Wang $(\bowtie)$

Department of Biology, Lakehead University,

955 Oliver Road,

Thunder Bay, ON, Canada P7B 5E1

e-mail: rwang@lakeheadu.ca

G. Yang

The School of Kinesiology, Lakehead University,

Thunder Bay, ON, Canada

G. Tang $\cdot$ L. Wu

Department of Pharmacology, University of Saskatchewan,

Saskatoon, SK, Canada inhibitive effects of high glucose on CSE protein production and promoter activity in INS-1E cells were also virtually abolished.

Conclusions/interpretation Glucose stimulates the phosphorylation of SP1 via p38 MAPK activation, which leads to decreased Cse promoter activity and subsequent downregulation of Cse gene expression. Inhibited $\mathrm{H}_{2} \mathrm{~S}$ production through glucosemediated CSE activity and production alterations may be involved in the fine control of glucose-induced insulin secretion.

Keywords CSE $\cdot$ Glucose $\cdot \mathrm{H}_{2} \mathrm{~S} \cdot \mathrm{INS}-1 \mathrm{E}$ cells $\cdot \mathrm{SP} 1$

$\begin{array}{ll}\text { Abbreviations } & \\ \text { CBS } & \text { Cystathionine } \beta \text {-synthase } \\ \text { CSE } & \text { Cystathionine } \gamma \text {-lyase } \\ \text { 2-DG } & \text { 2-Deoxy-D-glucose } \\ \text { K }_{\text {ATP }} \text { channels } & \text { ATP-sensitive } \mathrm{K}^{+} \text {channels } \\ \text { MA } & \text { Mithromycin A } \\ \text { MAPK } & \text { Mitogen-activated protein kinase } \\ \text { PPG } & \text { DL-Propargylglycine } \\ \text { SP1 } & \text { Specificity protein-1 }\end{array}$

\section{Introduction}

Study of $\mathrm{H}_{2} \mathrm{~S}$ has gained momentum in recent years as its role as an important gasotransmitter with multifaceted biological significance has become recognised. Gasotransmitters are a family of endogenous gaseous signalling molecules involved in multi-level regulation of physiological and pathological functions [1]. Following the identification of nitric oxide (NO) and carbon monoxide $(\mathrm{CO})$ as the first two gasotransmitters, mounting evidence has demonstrated that $\mathrm{H}_{2} \mathrm{~S}$ is the third one. 
$\mathrm{H}_{2} \mathrm{~S}$ is produced in various types of cells via the enzymatic function of two enzymes: cystathionine $\beta$-synthase (CBS) and cystathionine $\gamma$-lyase (CSE) [1]. CSE has been shown to be the predominant $\mathrm{H}_{2} \mathrm{~S}$-generating enzyme in pancreatic beta cells [2] and freshly isolated rat islets [3].

Activation of ATP-sensitive $\mathrm{K}^{+}\left(\mathrm{K}_{\mathrm{ATP}}\right)$ channels is demonstrated to be responsible for the inhibitory effect of $\mathrm{H}_{2} \mathrm{~S}$ on glucose-induced insulin release from INS-1E [2] and HIT-T15 cell lines [4]. As opening of $\mathrm{K}_{\mathrm{ATP}}$ channels leads to beta cell membrane hyperpolarisation, insulin release from pancreatic islets would be inhibited because of reduced $\mathrm{Ca}^{2+}$ influx. Exogenously applied $\mathrm{H}_{2} \mathrm{~S}$ or overproduction of CSE has been reported to induce apoptosis of INS-1E cells, suggesting an inhibitory effect of $\mathrm{H}_{2} \mathrm{~S}$ on insulin production by reduction of beta cell mass [2]. Glucose level has been seen to regulate various gene expressions in beta cells such as Glut2 (also known as Slc2a2) [5], acetyl-CoA carboxylase ( $A c c$ [also known as Acaca]) [6] and connexin 36 [7]. Previous research suggested a suppressive role of glucose on endogenous $\mathrm{H}_{2} \mathrm{~S}$ production in INS-1E cells [2]. Considering the critical role of glucose level on gene regulation in pancreatic beta cells and the effect of $\mathrm{H}_{2} \mathrm{~S}$ on insulin secretion, we planned to investigate if the production of CSE is regulated by glucose level in insulin-secreting cells and the underlying mechanism. Our results indicated that CSE production is inhibited by glucose at high concentrations. We further demonstrated that glucoseinduced downregulation of CSE production requires SP1 and $\mathrm{p} 38$ mitogen-activated protein kinase (MAPK) phosphorylation. The effect of high glucose on CSE production may constitute a novel regulatory mechanism for the fine control of insulin secretion from pancreatic beta cells.

\section{Methods}

Cell culture INS-1E cells were cultured as previously described by Yang et al. and used between passages 50 and 80 [2]. The experiments were performed when cultured cells reached $70-80 \%$ confluence. Before treatment with different concentrations of glucose, INS-1E cells were preincubated overnight in RPMI 1640 medium containing 1\% FBS and $5 \mathrm{mmol} / 1$ glucose at $37^{\circ} \mathrm{C}$ in a humidified mixture of $5 \% \mathrm{CO}_{2}$ and $95 \% \mathrm{O}_{2}$ (vol./vol.) and then subjected to different concentrations of glucose or other compounds together with $10 \%$ FBS.

Preparation of intact islets Pancreatic islets were isolated from male Sprague-Dawley rats $(8-12$ weeks) by the collagenase digestion method. The solution used for the isolation was KRB supplemented with $0.5-1 \mathrm{mg} / \mathrm{ml}$ collagenase type $\mathrm{V}, 0.5-1 \mu \mathrm{l} / \mathrm{ml}$ DNase I and $0.5 \mathrm{mg} / \mathrm{ml}$ bovine serum albumin. Animal experiments were conducted in compliance with the Guide for the Care and Use of Laboratory Animals published by the US National Institutes of Health (NIH Publication No. 85-23, revised 1996) and approved by the Animal Use Committee of Lakehead University, ON, Canada.

Measurement of endogenous $\mathrm{H}_{2} \mathrm{~S}$ production $\mathrm{H}_{2} \mathrm{~S}$ production rate was measured as previously described [8-10]. Briefly, INS-1E cells were incubated with either 5 or $20 \mathrm{mmol} / 1$ glucose for $24 \mathrm{~h}$, then collected and lysed in $50 \mathrm{mmol} / 1$ ice-cold potassium phosphate buffer $(\mathrm{pH} 6.8)$. The cell lysates were first incubated with L-cysteine $(10 \mathrm{mmol} / \mathrm{l})$ for $90 \mathrm{~min}$ at $37^{\circ} \mathrm{C}$, and then trichloroacetic acid was added to stop the reaction. The level of Methylene Blue generated by the interaction of $\mathrm{H}_{2} \mathrm{~S}$ with $N, N$ dimethyl- $p$-phenylenediamine sulphate was determined at $670 \mathrm{~nm}$ with a FLUOstar OPTIMA microplate spectrophotometer (BMG LABTECH, Offenburg, Germany). $\mathrm{H}_{2} \mathrm{~S}$ content in the culture medium was measured as previously described by Yang et al. [11].

Western blots Cultured cells were harvested and lysed in a Tris-EDTA sucrose lysis buffer plus protease inhibitors as previously described by Yang et al. [2]. Protein extracts were separated by SDS-PAGE and blotted onto nitrocellulose membranes (Pall Corporation, Pensacola, FL, USA) [12]. The primary antibodies used were: anti-CSE antibody (Abnova, Taiwan, Republic of China), anti-SP1 antibody (Santa Cruz Biotechnology, Santa Cruz, CA, USA), antiphospho SP1 (threonine 453) (Abcam, Cambridge, MA, USA), anti-phospho-p38 MAPK, anti-p38 MAPK (Cell Signaling Technology, Beverly, MA, USA) and $\beta$-actin (Sigma, Oakville, ON, Canada). Immunoreactions were visualised by ECL Western Blotting System (GE Healthcare, Amersham, UK). Densitometric quantification was performed using Alpha Digi Doctor software (Richardson, TX, USA) and normalised against the quantity of $\beta$-actin.

Short interfering RNA (siRNA) transfection Pre-designed $S p 1$-targeted siRNA (Spl-siRNA) and control siRNA were purchased from Santa Cruz. INS-1E cells were seeded in six-well plates at a density of $1 \times 10^{5}$ cells per well in the presence of $5 \mathrm{mmol} / \mathrm{l}$ glucose. Transfection of siRNA into INS-1E cells was achieved using Lipofectamine 2000 Transfection Reagent (Invitrogen, Burlington, ON, USA). Briefly, the cells were transfected with $20 \mathrm{nmol} / \mathrm{l} \mathrm{Sp1-}$ siRNA or control-siRNA in Opti-MEM I culture medium (Invitrogen) without antibiotics for $4 \mathrm{~h}$. Fresh normal growth medium was then added and the cells were incubated for another $44 \mathrm{~h}$. 
Determination of $m R N A$ level by real-time PCR INS-1E cells were harvested and the total RNA was isolated using TriReagent. First-strand cDNA was prepared by reverse transcription using $\mathrm{M}-\mathrm{MuLV}$ reverse transcriptase and random hexamer primers from a ProtoScript II RT-PCR Kit (New England Biolabs, Pickering, ON, Canada) according to the manufacturer's protocol. The primers of rat Cse (GenBank accession number AY032875) were 5'-AGCGATCACAC CACA-GACCAAG-3' and 5'-ATCAGCACCCAGAGC CAAAGG-3'. Quantum RNA $\beta$-actin internal standards were purchased from Ambion (Foster City, CA, USA). Real-time PCR was performed in an iCycler IQ 5 apparatus (Bio-Rad, Mississauga, ON, Canada) associated with the iCycler optical system software (version 3.1) using SYBR Green PCR Master Mix and relative mRNA quantification was calculated as described previously $[2,11]$.

Cloning of mouse Cse promoter region and construction of reporter plasmids The 172 bp genomic DNA fragment upstream from the transcriptional start site $(-149$ to +23$)$ of the Cse gene, containing canonical TATA and CAAT boxes and the SP1 site, was isolated by PCR from mouse-tail genomic DNA [13]. Briefly, the small fragment was amplified using $1.5 \mu \mathrm{g}$ mouse genomic DNA as template in a $20 \mu \mathrm{l}$ volume reaction with $5 \mathrm{pmol} / \mu \mathrm{l}$ of each primer. The sequences of the primers used were as follows: F-CseSpl (KpnI) (-149/-134), 5'-CGGTACCTCTGTGC CACTGGGAG-3'; R-Cse-Spl (HindIII) (+7/+23), 5'GAAGCTTGAGTGCGAGGTGTTGCT-3'. The underlined sequence is the restriction site for KpnI or HindIII. The cloned fragments were subcloned into the promoterless expression vector pGL3 basic (Promega, Madison, WI, USA) to obtain the reporter plasmid pGL3 (-149/+23)-CseProm-Luc. Another plasmid was constructed, which was derived from the pGL3 $(-149 /+23)$-Cse-Prom-Luc, and contained a mutated SP1 site. The SP1 response element (5'-GAGGCGGGGC-3') was mutated into (5'GATTCGGGGC-3') by using QuikChange Site-Directed Mutagenesis Kit (Stratagene, Mississauga, ON, USA), with oligonucleotide (-144 to -117) 5'-GCCACTGGGATTCGGGGCAGGAACGATC-3' and its complementary oligonucleotide according to the manufacturer's recommendations. The mutations are underlined and in italic letters. All plasmid constructs were verified by DNA sequencing.

Transient transfection and luciferase assay INS-1E cells were transfected with $900 \mathrm{ng}$ of the reporter plasmid pGL3 (-149/+23)-Cse-Prom-Luc DNA (CSE-Spl vector), mutated-Spl promoter or pGL3-basic vector, mixed with $100 \mathrm{ng}$ pRL-TK vector (Promega) as an internal control using Lipofectamine 2000. Six hours after the transfection, the OptiMEM medium was replaced by RPMI 1640 medium with 5 or $20 \mathrm{mmol} / \mathrm{l}$ glucose in the presence or absence of $10 \mu \mathrm{mol} / 1$ p38 MAPK inhibitors SB203580, SB202190 or their non-active analogue SB202474 and incubated for another $24 \mathrm{~h}$ before harvesting with passive lysis buffer (Promega). Samples of the lysates were assayed for luciferase activities in a Fluostar Luminometer (BMG LABTECH, Germany) using the Dual-Luciferase Reporter Assay System (Promega). Both firefly and Renilla luciferase activities were measured as luminescence intensities and the promoter activity was expressed as ratios between firefly and Renilla luciferase activities.

Measurement of insulin secretion from INS-1E cells INS$1 \mathrm{E}$ cells were washed and pre-incubated with glucose-free KRB (pH 7.4) plus $0.1 \%$ BSA in 24-well plates. After 30 min pre-incubation, cells were incubated for another $30 \mathrm{~min}$ at $37^{\circ} \mathrm{C}$ in the presence of different glucose concentrations with or without $5 \mathrm{mmol} / 1$ DL-propargylglycine (PPG), $20 \mathrm{mmol} / \mathrm{l}$ sodium pyruvate or $20 \mathrm{mmol} / \mathrm{l}$ 2-deoxy-D-glucose (2-DG). Where sodium salts of pyruvate were added, the $\mathrm{Na}^{+}$content of the KRB was correspondingly decreased. At the end of each incubation period, the medium was collected and immediately stored at $-20^{\circ} \mathrm{C}$ until insulin determination was completed by using the rat insulin ELISA kit (Mercodia AB, Sylveniusgatan, Uppsala, Sweden).

Materials and data analysis Chemicals were all obtained from Sigma (Oakville, ON, Canada) unless otherwise mentioned. Unless otherwise specified, 'glucose' refers to D-glucose in this communication. The data are expressed as mean \pm SEM from at least three independent experiments. Statistical analyses were performed using Student's $t$ test on paired data or one-way ANOVA. Statistical significance was considered at $p<0.05$.

\section{Results}

High glucose suppressed $\mathrm{H}_{2} \mathrm{~S}$ release from INS-1E cells and pancreatic islets High glucose $(20 \mathrm{mmol} / \mathrm{l})$ lowered $\mathrm{H}_{2} \mathrm{~S}$ content of the culture media by $42.1 \pm 2.8 \%(n=6, p<0.05)$ for INS-1E cells (Fig. 1a) and 76.4 $\pm 1.8 \%(n=3, p<0.05)$ for freshly isolated rat pancreatic islets (Fig. 1b) compared with that treated with $5 \mathrm{mmol} / \mathrm{l}$ glucose. High glucose also decreased $\mathrm{H}_{2} \mathrm{~S}$ production rate in INS-1E cells $(n=4$; $p<0.05$; Fig. 1c).

High glucose decreased Cse mRNA expression and CSE protein production in INS-1E cells After incubation with high glucose for $24 \mathrm{~h}$, CSE protein production was significantly decreased (Fig. 2a). Cse mRNA level in INS- 

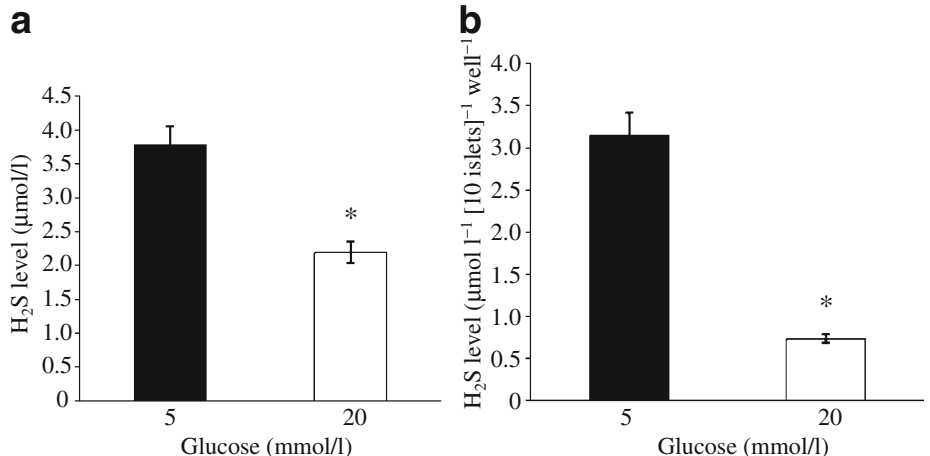

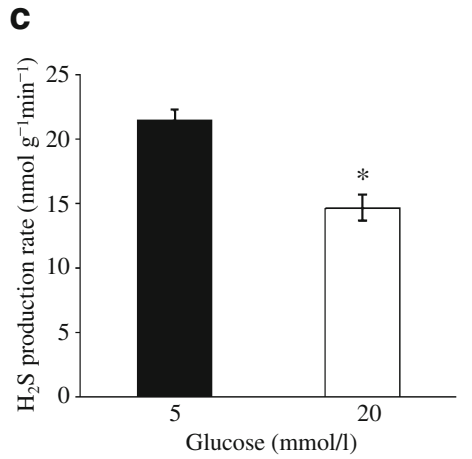

Fig. 1 High glucose inhibited $\mathrm{H}_{2} \mathrm{~S}$ production from INS-1E cells and freshly isolated rat islets. INS-1E cells and freshly isolated rat islets were cultured overnight in $5 \mathrm{mmol} / 1$ glucose medium with $1 \% \mathrm{FBS}$, and then changed to 5 or $20 \mathrm{mmol} / 1$ glucose medium with $10 \%$ FBS for another $24 \mathrm{~h}$. High glucose significantly inhibited $\mathrm{H}_{2} \mathrm{~S}$ production

$1 \mathrm{E}$ cells treated with $20 \mathrm{mmol} / \mathrm{l}$ glucose was $36.5 \pm 9.9 \%$ of that with $5 \mathrm{mmol} / \mathrm{l}$ glucose (Fig. 2b). To test if the decreased Cse gene expression occurred at the transcriptional level, INS-1E cells pre-incubated for $24 \mathrm{~h}$ in 5 or $20 \mathrm{mmol} / \mathrm{l}$ glucose medium were then exposed to actinomycin D $(5 \mu \mathrm{mol} / \mathrm{l})$ for 0.5 or $2 \mathrm{~h}$ (Fig. $2 \mathrm{c})$. Inhibition of RNA synthesis with actinomycin D in the presence of $20 \mathrm{mmol} / \mathrm{l}$ glucose did not lead to further reduction in the Cse mRNA level compared with $5 \mathrm{mmol} / \mathrm{l}$ glucose incubation, suggesting that glucose may not affect Cse mRNA stability. Therefore, it repressed the expression of Cse mRNA at the level of transcription.

Effects of pharmacological treatments on the production of CSE Western blots results showed that $20 \mathrm{mmol} / 1$ 2-DG mimicked the inhibitive effect of $20 \mathrm{mmol} / \mathrm{l}$ glucose on CSE production in INS-1E cells (Fig. 3a) and rat islets (Fig. 3b). Pyruvate at $20 \mathrm{mmol} / 1$ significantly decreased CSE production in both INS-1E cells (Fig. 3a) and isolated in the culture medium for INS-1E cells (a) and pancreatic rat islets (b). $\mathrm{H}_{2} \mathrm{~S}$ production rate in INS-1E cells (c) was also significantly decreased by high glucose. Data in (a) and (b) were from at least three independent experiments; data in (c) were from four independent experiments. ${ }^{*} p<0.05$

rat islets (Fig. 3b), whereas $20 \mathrm{mmol} / \mathrm{lL}$-glucose and mannitol were ineffective. To explore whether beta cell depolarisation affects glucose-induced downregulation of CSE production, INS-1E cells were incubated with $5 \mathrm{mmol} / \mathrm{l}$ glucose in the presence of $\mathrm{KCl}(20 \mathrm{mmol} / \mathrm{l}) . \mathrm{KCl}$ treatment did not alter CSE production (Fig. 3a).

High-glucose-modulated CSE production requires the phosphorylation of $p 38$ MAPK and SP1 The phosphorylation of p38 MAPK in INS-1E cells was evident within $15 \mathrm{~min}$ of high glucose treatment and peaked at $1 \mathrm{~h}$ (Fig. 4a). High-glucose-induced phosphorylation of SP1 protein without changing the amount of total SP1 protein (Fig. 4b). SB203580 and SB202190 (p38 MAPK inhibitor) but not SB202474 at $10 \mu \mathrm{mol} / 1$ abolished the inhibitive effect of high glucose on CSE production. Moreover, inhibition of the SP1 binding to the GC boxes of promoter by $100 \mathrm{nmol} / \mathrm{l}$ mithromycin A (MA) induced a greater decrease of CSE production (Fig. 4c).

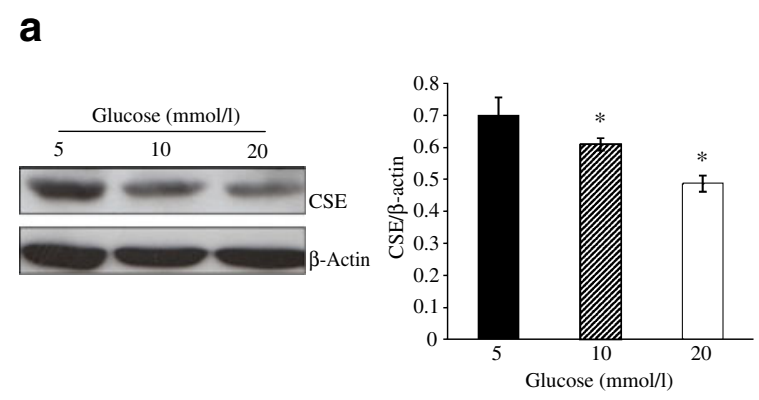

Fig. 2 High glucose downregulated Cse mRNA and CSE protein production in INS-1E cells. After INS-1E cells were incubated with the indicated concentration of glucose for $24 \mathrm{~h}$, the cells were collected and subjected to western blots (a) and real-time PCR (b) analyses. (c) Glucose had no effect on the stability of the Cse transcript. INS-1E cells were pre-incubated with 5 or $20 \mathrm{mmol} /$
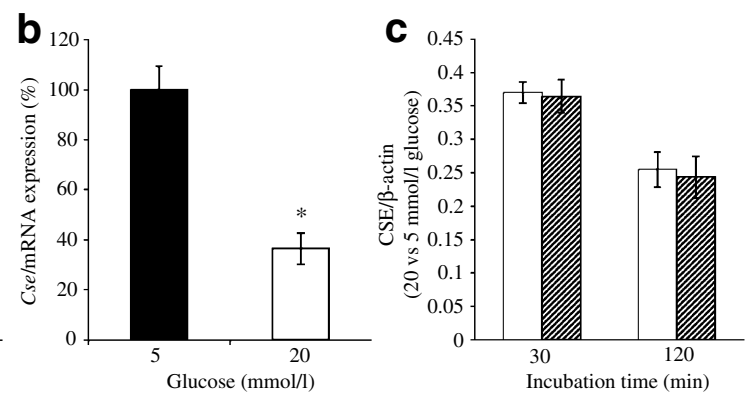

1 glucose for $24 \mathrm{~h}$, and then treated in the absence (white bars) or presence of $5 \mu \mathrm{mol} / 1$ actinomycin D (striped bars) for 0.5 or $2 \mathrm{~h}$. The data were normalised to $\beta$-actin production and are presented relative to production at $5 \mathrm{mmol} / \mathrm{l}$ glucose. In (a) and (b) the data are from four independent experiments; in (c) the data are from three independent experiments. ${ }^{*} p<0.05$ 
Fig. 3 Effect of pharmacological treatments on the production of CSE. INS-1E cells (a) and pancreatic rat islets (b) were incubated with 5 or $20 \mathrm{mmol} / \mathrm{l}$ D-glucose, $20 \mathrm{mmol} / \mathrm{l}$ pyruvate, $20 \mathrm{mmol} / \mathrm{l} 2-\mathrm{DG}, 20 \mathrm{mmol} / \mathrm{l}$ $\mathrm{KCl}$ in the presence of $5 \mathrm{mmol} / \mathrm{l}$ D-glucose, $20 \mathrm{mmol} / \mathrm{l}$ mannitol or $20 \mathrm{mmol} / \mathrm{l} \mathrm{L}$-glucose for $24 \mathrm{~h}$, respectively. After that, the cells or islets were collected and subjected to western blot analysis. The data are from three independent experiments. ${ }^{*} p<0.05$ vs $5 \mathrm{mmol} / \mathrm{l}$ D-glucose. Glu, glucose; Pyr, pyruvate a

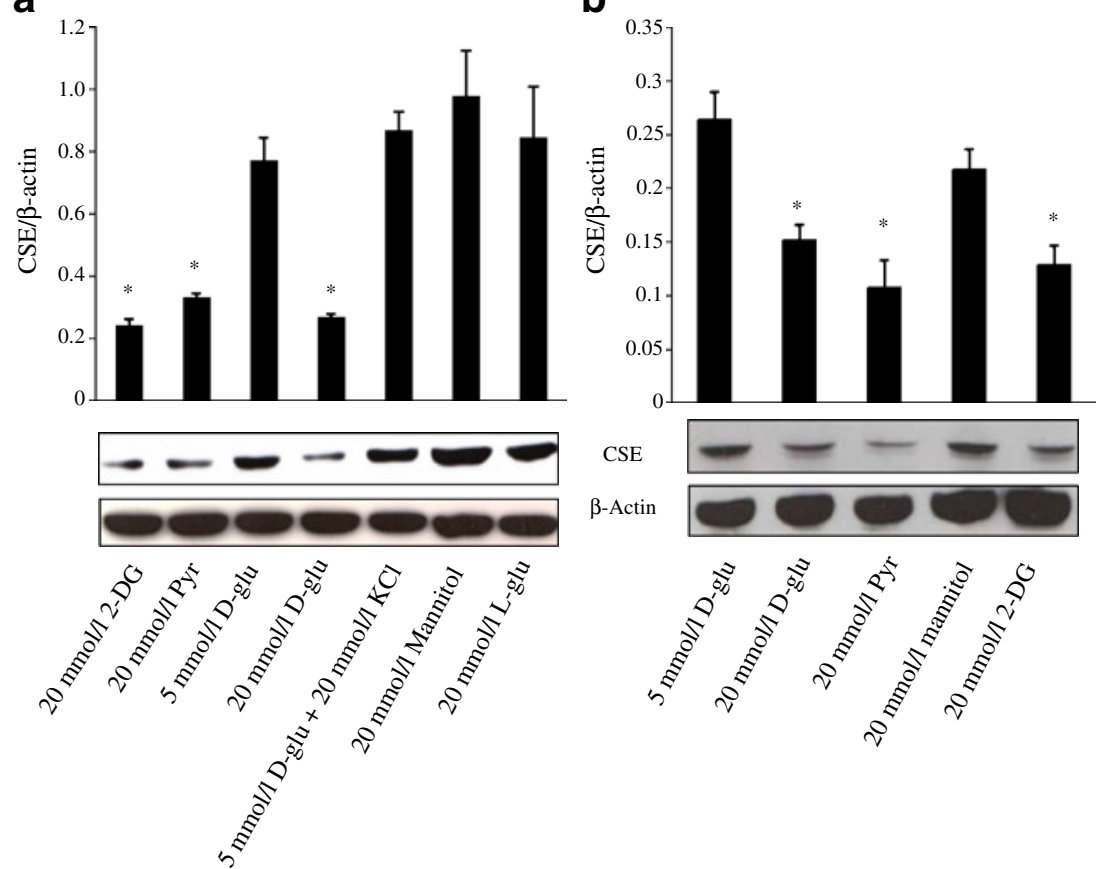

Role of p38 MAPK in glucose-induced phosphorylation of SP1 To confirm the observation that p38 MAPK is involved in SP1-mediated glucose deactivation of CSE, we examined the effects of p38 MAPK inhibitors on glucose-induced change in production of phospho and total SP1. Pretreatment with two specific p38 MAPK inhibitors, SB203580 and SB202190 (both $10 \mu \mathrm{mol} / \mathrm{l}$ ), drastically decreased glucose-induced phosphorylation of SP1 without changing the amount of total SP1 compared with the control reagent SB202474, DMSO (1\%) or high glucose alone (Fig. 5a). Furthermore, the effects of Spl-specific siRNA on Cse expression were determined at protein levels (Fig. 5b). Transfection of Spl-specific siRNA significantly reduced CSE production. These results indicated an important role of SP1 in CSE production.

p38 MAPK-SP1 signalling pathway mediated high-glucoseinduced decrease of Cse promoter activity Transfection of INS-1E cells with Cse core promoter (Cse-Spl promoter) resulted in a 39-fold increase in luciferase activation in the presence of $5 \mathrm{mmol} / \mathrm{l}$ glucose $(n=5 ; * p<0.01$ vs cells transfected with the promoterless pGL3 basic vector). However, Cse-Spl promoter activity was inhibited significantly by high glucose $(20 \mathrm{mmol} / \mathrm{l})$. Mutating the consensus SP1 binding site completely abolished Cse core promoter (Cse-Spl promoter) activity (Fig. 6a). By inhibiting p38 MAPK, SB202190 and SB203580 completely abolished the inhibitory effect of $20 \mathrm{mmol} / \mathrm{l}$ glucose on Cse promoter activity in the presence or absence of $10 \mu \mathrm{mol} / 1 \mathrm{SB} 202474$ (Fig. 6b).
PPG, but not pyruvate or 2-DG, enhances high-glucoseinduced insulin secretion High glucose $(20 \mathrm{mmol} / \mathrm{l})$ stimulated insulin secretion from INS-1E cells by approximately threefold compared with the basal glucose $(5 \mathrm{mmol} / \mathrm{l})$. After treatment with $5 \mathrm{mmol} / \mathrm{l} \mathrm{PPG}$ to inhibit CSE activity, insulin secretion at basal glucose was not altered. However, high-glucose-stimulated insulin secretion was slightly but significantly increased (Fig. 7a). Conditions of $20 \mathrm{mmol} / 1$ $2-\mathrm{DG}$ alone or in the presence of $5 \mathrm{mmol} / \mathrm{l}$ glucose did not stimulate insulin secretion. However, in the presence of $20 \mathrm{mmol} / \mathrm{l}$ glucose, 2-DG significantly inhibited glucoseinduced insulin secretion. Pyruvate $(20 \mathrm{mmol} / \mathrm{l})$ had no effect on insulin release in the presence or absence of glucose within 30 min of application (Fig. 7b).

\section{Discussion}

Endogenous $\mathrm{H}_{2} \mathrm{~S}$ level in pancreatic beta cells plays a critical role in regulating insulin release. $\mathrm{H}_{2} \mathrm{~S}$ has been shown to inhibit insulin secretion from insulin-secreting cell lines (INS-1E, MIN6 and HIT-T15) and isolated islets $[2,4,14,15] . \mathrm{H}_{2} \mathrm{~S}$ has also been linked to glucose metabolism and insulin resistance by interaction with methylglyoxal, an intermediate of glucose metabolism [16] and by inhibiting basal and insulin-stimulated glucose uptake in adipocytes [17].

Pancreatic production of $\mathrm{H}_{2} \mathrm{~S}$ is regulated by CSE and/or CBS [2, 4, 14, 15]. Cse gene knockdown by Cse-siRNA 


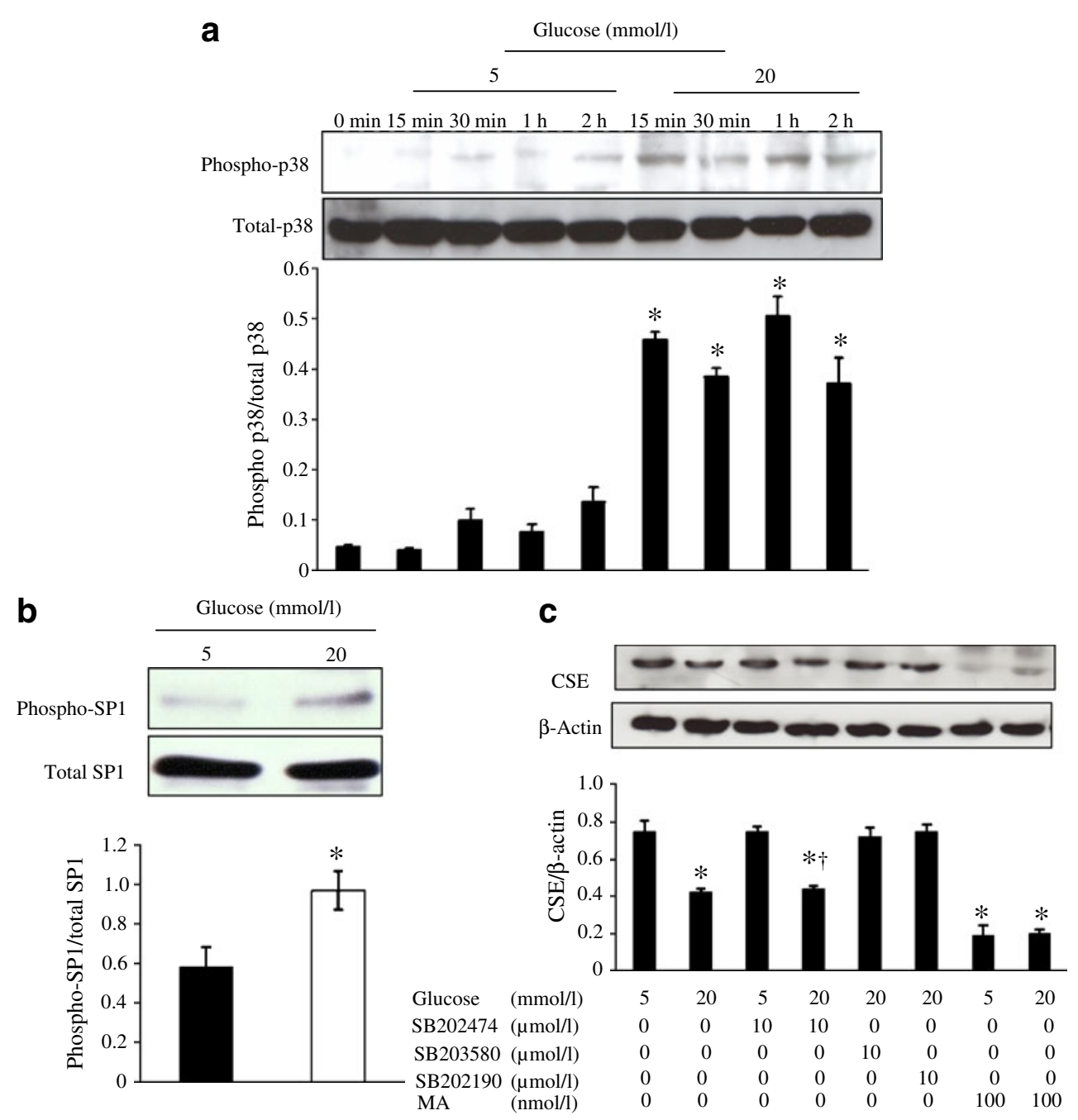

Fig. 4 Glucose stimulated phosphorylation of p38 MAPK and SP1. (a) Glucose induced phosphorylation of p38 MAPK. INS-1E cells were incubated with glucose at 5 or $20 \mathrm{mmol} / 1$ for the indicated time. After that, the cells were collected and subjected to western blot analysis. ${ }^{*} p<0.05$ vs $5 \mathrm{mmol} / \mathrm{l}$ glucose treatment group at the same time point. (b) Glucose stimulated SP1 phosphorylation. INS-1E cells were pretreated with $5 \mathrm{mmol} / \mathrm{l}$ glucose RPMI-1640 medium containing $1 \%$ FBS overnight and then incubated with $5 \mathrm{mmol} / \mathrm{l}$ or $20 \mathrm{mmol} / \mathrm{l}$ glucose

largely eliminated $\mathrm{H}_{2} \mathrm{~S}$ production from INS-1E cells [2]. We reported significant production levels of CSE in rat pancreatic islets, but $C b s$ mRNA expression was extremely low [3]. PPG, as a specific CSE inhibitor, drastically reduced $\mathrm{H}_{2} \mathrm{~S}$ production rate to near zero in pancreatic islets from both Zucker diabetic fatty and Zucker fatty rats. Taken these together, it is believed that CSE is the main enzyme for $\mathrm{H}_{2} \mathrm{~S}$ production in rat pancreatic beta cells and the INS$1 \mathrm{E}$ cell line.

High glucose is capable of regulating the expression of many genes in pancreatic beta cells [18]. For example, Glut2 [5] and Acc [6] were upregulated by glucose, whereas for $24 \mathrm{~h}$. After that, the cells were collected and subjected to western blot analysis. ${ }^{*} p<0.05$. (c) The $\mathrm{p} 38$ MAPK-SP1 pathway mediated the effect of glucose on CSE production. INS-1E cells were pretreated with or without SB203580, SB202190 or SB202474 (control reagent) for $1 \mathrm{~h}$, and then incubated with glucose at 5 or $20 \mathrm{mmol} / \mathrm{l}$ for $24 \mathrm{~h}$ in the presence or absence of $100 \mathrm{nmol} / \mathrm{l} \mathrm{MA} .{ }^{*} p<0.01$ vs $5 \mathrm{mmol} / 1$ glucose alone group; ${ }^{\dagger} p<0.01$ vs $5 \mathrm{mmol} / 1$ glucose with SB202474 group. The data are from three independent experiments

Cx36 (also known as Gjd2) [7], Ppara (also known as Ppara) [19] and those encoding the sulfonylurea receptor 1/inwardly rectifying $\mathrm{K}^{+}$channel 6.2 (Sur/Kir6.2 [also known as $A b c c 8 / K c n j 11]$ ) [20] were downregulated by high glucose. We have previously demonstrated that endogenous $\mathrm{H}_{2} \mathrm{~S}$ production rate in INS-1E cells was modulated by different glucose levels [2]. The underlying molecular mechanism for the interaction of high glucose and $\mathrm{H}_{2} \mathrm{~S}$ production, however, had been unclear. In this study, we found that high glucose inhibited CSE activity represented by decreased $\mathrm{H}_{2} \mathrm{~S}$ production rate within $2 \mathrm{~h}$ (data not shown). Also for the first time, we demonstrated 
a
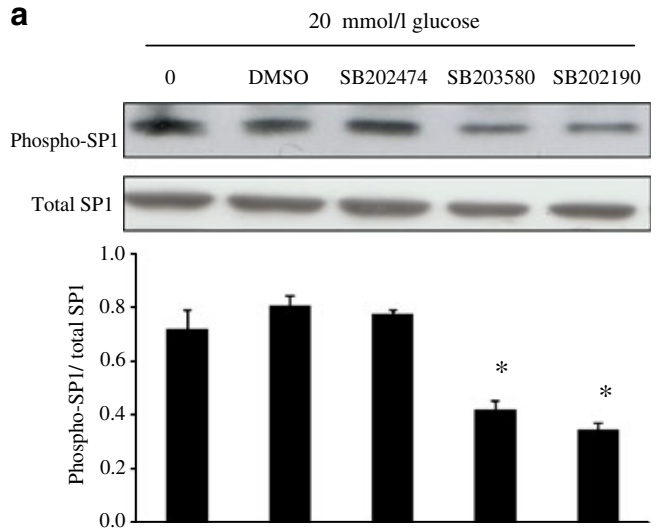

b

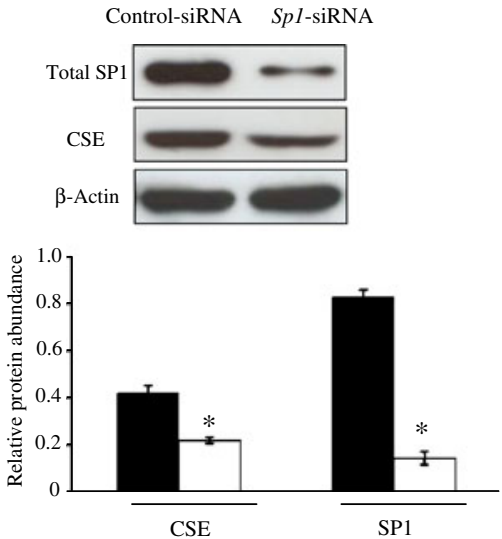

Fig. 5 Role of SP1 in glucose-induced regulation of CSE. INS-1E cells were cultured in $5 \mathrm{mmol} / \mathrm{l}$ glucose RPMI-1640 medium containing 1\% FBS overnight, and were changed on the next day to fresh medium ( $5 \mathrm{mmol} / 1$ glucose), pretreated with or without $0.1 \%$ DMSO (vehicle), $10 \mu \mathrm{mol} / 1 \mathrm{SB} 202474, \mathrm{SB} 203580$ or SB202190 for $1 \mathrm{~h}$, respectively, and then incubated with $20 \mathrm{mmol} / \mathrm{l}$ glucose for an additional $24 \mathrm{~h}$. Production of SP1 and phosphorylated SP1 was detected by western blot using specific antibodies. (a) p38 MAPK inhibitors SB203580 and SB202190 but not non-active analogue SB202474 decreases high-glucose-induced SP1 phosphorylation in INS-1E cells without changing total SP1 production. ${ }^{*} p<0.05 \mathrm{vs}$ control at $20 \mathrm{mmol} / 1$ glucose alone. (b) INS-1E cells were transfected with either control siRNA (black bars) or Sp1siRNA (white bars) for $48 \mathrm{~h}$ at $5 \mathrm{mmol} / 1$ glucose RPMI-1640 medium. Western blot analysis showed successful Spl knockdown and reduced CSE production in INS-1E cell lines. The data were normalised and are presented as ratio to $\beta$-actin production. The data are from three independent experiments. ${ }^{*} p<0.05$

CSE production was repressed by high glucose. Therefore, high glucose would both downregulate CSE production and inhibit CSE activity. The latter may be a relatively rapid mechanism for mediating glucose-induced insulin secretion.

We further investigated whether this inhibitory effect of glucose on CSE production is specifically related to cellular metabolism and use of glucose. L-Glucose, an analogue of glucose that cannot enter beta cell [21], had no effect on CSE protein abundance. The inhibitory effect of $20 \mathrm{mmol} / 1$ glucose on CSE production is also unlikely to be due to osmolality change as $20 \mathrm{mmol} / \mathrm{l}$ mannitol did
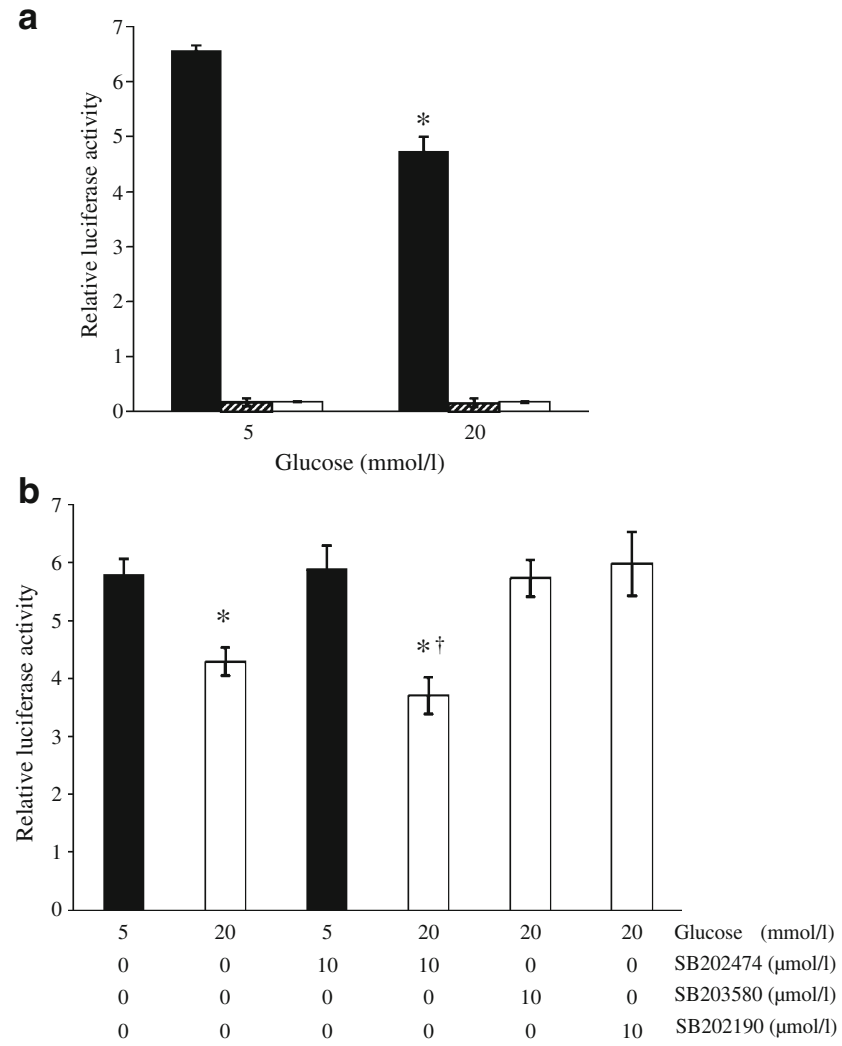

Fig. 6 Effect of glucose on mouse CSE promoter activity. (a) High glucose attenuated CSE promoter activity. INS-1E cells were cotransfected with reporter plasmids $C s e-S p 1$ vector (black bars), pGL3basic vector (shaded bars) or mutated-Spl construct (white bars) together with pRL-TK vector for $6 \mathrm{~h}$, then incubated in 5 or $20 \mathrm{mmol} / \mathrm{l}$ glucose RPMI-1640 medium for an additional $24 \mathrm{~h}$. Relative luciferase activity was normalised with Renilla luciferase from $\mathrm{pRL}-\mathrm{TK}$ vector. The data were from five independent experiments. ${ }^{*} p<0.01$ vs $5 \mathrm{mmol} / \mathrm{l}$ glucose alone group. (b) SB203580 and SB202190 but not SB202474 reversed glucose-reduced CSE promoter activity. INS-1E cells were transfected with $\mathrm{Cse}-\mathrm{Sp} 1$ vector in the presence or absence of the indicated concentration of glucose or inhibitors for $24 \mathrm{~h}$. Relative luciferase activity was normalised with Renilla luciferase from pRL-TK vector. The data were from four independent experiments. ${ }^{*} p<0.01 \mathrm{vs}$ $5 \mathrm{mmol} / \mathrm{l}$ glucose alone group; ${ }^{\dagger} p<0.01$ vs $5 \mathrm{mmol} / 1$ glucose plus SB202474 group

not alter CSE production. Another analogue of glucose, 2-DG, can be taken up by beta cells through GLUT2 transporters and phosphorylated by glucokinase but cannot be metabolised beyond the level of glucose 6-phosphate in the glycolytic or pentose-phosphate pathway [22]. Interestingly, 2-DG inhibited CSE production (Fig. 3). This phenomenon suggests that glucose 6-phosphate may be key to the glucose-induced downregulation of CSE production. Brun et al. [6] reported previously that a wide variety of metabolisable nutrients were incapable of inducing Acc mRNA in the INS-1 cell line. However, 2-DG was capable of inducing Acc mRNA, suggesting that glucose does not have to be metabolised beyond glucose 6-phosphate in the glycolytic pathway to induce 

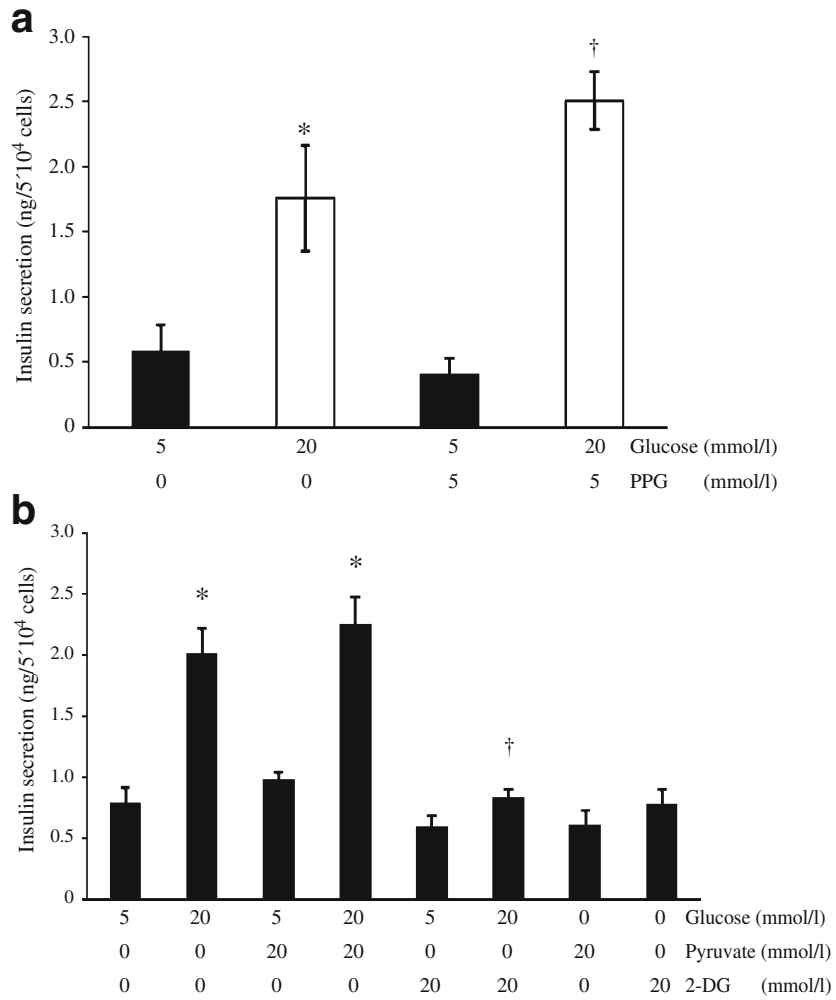

Fig. 7 Inhibition of CSE activation enhanced glucose-induced insulin secretion. After 30 min pre-incubation with glucose-free KRB, INS$1 \mathrm{E}$ cells were incubated for another $30 \mathrm{~min}$ at $37^{\circ} \mathrm{C}$ in the presence of different glucose concentrations with or without $5 \mathrm{mmol} / 1 \mathrm{PPG}$ (a), $20 \mathrm{mmol} / 1$ pyruvate or 2-DG (b). Insulin level in the culture media was measured by ELISA. The data were from four independent experiments. ${ }^{*} p<0.05$ vs $5 \mathrm{mmol} / 1$ glucose alone group. ${ }^{\dagger} p<0.05$ vs $20 \mathrm{mmol} / \mathrm{l}$ glucose alone group

production of this gene product. Further studies are merited to determine the direct effect of glucose 6-phosphate on CSE production to confirm this hypothesis. Pyruvate also significantly decreased CSE protein production even more than high glucose did in rat islets (Fig. 3b). This result indicates that pyruvate, a product of a CSE-catalysed reaction, may inhibit CSE production as a product-based feedback control mechanism.

As 2-DG and pyruvate decreased the production of CSE, it would be expected that the consequently lowered endogenous $\mathrm{H}_{2} \mathrm{~S}$ level might promote insulin release, the same effect as offered by PPG (Fig. 7a). However, as the application of 2-DG and pyruvate in the insulin release experiments was limited to $30 \mathrm{~min}$, CSE protein level would not be changed within this short period of time. We also found that 2-DG and pyruvate alone had no effect on $\mathrm{H}_{2} \mathrm{~S}$ production rate in INS-1E cells, which reflects CSE activity (data not shown). Taken together, the effects of 2-DG and pyruvate on insulin release (Fig. 7b), if any, could not be ascribed to changed CSE production or activity. Indeed, $20 \mathrm{mmol} / \mathrm{l}$ 2-DG significantly inhibited the insulin release stimulated by $20 \mathrm{mmol} / \mathrm{l}$ glucose. Similar results had been reported previously that $2-\mathrm{DG}$ at $17 \mathrm{mmol} / 1$ decreased insulin release from rat pancreas [23]. The underlying mechanism for this interaction of 2-DG and glucose may be related to the competition of 2-DG with glucose for transportation into the cells [24] and for reaction with glucokinase or hexokinase within the cell [25-27].

Glucose metabolism stimulates insulin secretion by closing $\mathrm{K}_{\mathrm{ATP}}$ channels and subsequent calcium influx, eventually leading to exocytosis of insulin granules. To examine if glucose-induced depolarisation of beta cells is responsible for CSE downregulation, INS-1E cells were treated with $20 \mathrm{mmol} / 1 \mathrm{KCl}$ in the presence of basal glucose. This treatment did not alter CSE production (Fig. 3a). Similar results were obtained from freshly isolated islets under the same treatments (Fig. 3b). These results suggested that $\mathrm{Ca}^{2+}$ influx-mediated insulin secretion was not implicated in glucose-repressed CSE production.

The human CSE and rodent Cse genes have been cloned before $[13,28]$. The core promoter of mouse Cse contains several putative transcriptional factor-binding sites, including myeloid zinc finger protein 1 (MZF-1) and SP1 [13]. Deletion of Mzfl (in Cos-7 and HEK-293 cells) or $S p 1$ consensus sequence (in HEK-293 cells) from Cse promoter significantly decreased the promoter activity, suggesting the involvement of these factors in the basal transcriptional activity of Cse. Bioinformatics analysis of the promoter region of the mouse and rat $C s e$ also revealed the presence of a potential $S p 1$ consensus sequence $\left(5^{\prime}\right.$ GAGGCGGGGC-3') located within the $-149 /+23$ region of the mouse Cse promoter and at $-182 /-173$ region in the rat Cse promoter. Previous investigation found that the -137 to +18 sequence conferred the highest promoter activity in HEK-293 cells using the promoter deletion and mutation method [13]. Given that the use of mouse Cse promoter has been examined thoroughly, and SP1 is a ubiquitous transcription factor abundantly expressed in different species with a highly conservative consensus sequence of 'GAGGCGGGGC', we generated a pGL3 (-149/+23)-Cse-promoter expression vector (Cse-Sp1 vector) cloned upstream to luciferase and used it to transfect INS-1E cells. We demonstrated that SP1 is a crucial transactivator for Cse gene expression because transfection of INS-1E cells with this $C s e$ core promoter containing the $S p 1$ consensus sequence (Cse-Spl vector) resulted in a 39-fold increase in luciferase activity compared with promoterless vector (Fig. 6a). MA binds to GC-rich regions in chromatin and interferes with the transcription of genes bearing GC-rich motifs in their promoter. It is also known as a major SP1 inhibitor, as SP1 recognises GC-rich sequences [29]. It drastically decreased CSE production in the presence of either $5 \mathrm{mmol} / \mathrm{l}$ or $20 \mathrm{mmol} / \mathrm{l}$ glucose (Fig. 4c). Sp1 knockdown also abolished a large portion of CSE protein 
production (Fig. 5b), suggesting a critical role of SP1 in CSE production. A single $S p 1$ site mutation of $C s e-S p 1$ vector completely abolished the promoter activity of Cse (Fig. 5a), again suggesting the importance of Spl in the basal transcriptional activity of Cse. High-glucose treatment significantly attenuated SP1 transactivation, which provided evidence that a glucose-responsive element is located within the proximal portion of the mouse Cse promoter (Fig. 6a, b).

Several reports have suggested the ubiquitously produced transcription factor SP1 may provide a mechanism for glucose responsiveness [30, 31]. Changes in SP1 phosphorylation result in either facilitation or suppression of DNA binding, promoter activation [31-33] and gene transcription [34-36]. SP1 protein can be phosphorylated at various sites by different kinases including protein kinase A, protein kinase $\mathrm{C}$, MAPK, casein kinases 1 and 2, and calmodulin kinases [37]. It was previously reported that glucose can de-phosphorylate SP1 and increase promoter binding activity on the $A c c$ gene in adipose tissue [38]. The phosphorylation status of SP1 appears to be cell- and genetype dependent, which is also a major factor in mediating the effects of extracellular stimuli such as insulin [39].

In the present study, we examined possible signaltransduction pathways related to SP1 phosphorylation in high-glucose-induced downregulation of Cse expression. Exposure to high glucose has been reported to lead to the activation of various MAPK cascades in pancreatic beta cell lines [40, 41]. While p38 MAPK phosphorylation became significant 15 min after high-glucose treatment (Fig. 4a), the decreased Cse mRNA and protein levels were detected $24 \mathrm{~h}$ later. Whether the downregulation of Cse mRNA expression actually occurred immediately after p38 MAPK phosphorylation was not tested. It is reasoned that, however, p38 MAPK phosphorylation functions as a trigger and the decreased CSE production followed. This effect of high glucose is relatively specific as no significant difference was found in phospho-p44/42 MAPK level between 5 and $20 \mathrm{mmol} / \mathrm{l}$ glucose treatments (data not shown). Inhibition of p38 MAPK phosphorylation by SB203580 or SB202190 at $20 \mathrm{mmol} / 1$ glucose significantly decreased SP1 phosphorylation without changing the amount of total SP1 protein (Fig. 5a), indicating that high glucose phosphorylates the existing SP1 protein through p38 MAPK. SB203580 and SB202190 but not SB202474 also completely reversed the inhibitory effect of high glucose on CSE production (Fig. 4c). Moreover, inhibition of SP1 phosphorylation by SB203580 or SB202190 abolished the inhibitive effect of glucose to CSE promoter activity (Fig. 6b). These novel observations suggest that high glucose increases phosphorylation of SP1 via p38 MAPK activation in INS-1E cells, resulting in a decreased CSE promoter activity and reduced Cse transcription.
Kaneko et al. [42] reported glucose-induced $\mathrm{H}_{2} \mathrm{~S}$ production by observing stimulated CSE production after $18 \mathrm{~h}$ incubation with high glucose in mouse islets and MIN6 cells. The discrepancies between the present study and the findings of Kaneko et al. may be resolved by considering that $\mathrm{H}_{2} \mathrm{~S}$ level is not directly assayed in their study and glucose level in the pre-incubation before treatment was not indicated. The discrepancy may also be related to different responses of different cell types or animal species to $\mathrm{H}_{2} \mathrm{~S}$ and other experimental conditions. The reported effects of $\mathrm{CSE} / \mathrm{H}_{2} \mathrm{~S}$ on the survival/apoptosis of pancreatic beta cells are not consistent either [11, 42]. We did not find any reduced cell viability after incubation with high glucose for $24 \mathrm{~h}$ compared with basal glucose (data not shown). Our observation was supported by another study in which high glucose promoted pancreatic islet beta cell survival through phosphatidylinositol-3kinase/Akt signalling at $24 \mathrm{~h} \mathrm{[43].}$

Our study did not directly test whether the phosphorylation of SP1 at the Thr453 leads to reduced SP-1 binding to the Cse promoter region. A reduced transcriptional or promoter activity is not always accompanied by reduced DNA binding [44]. Transcription activity could be regulated through changes in the interaction between SP1 and other regulatory factors as a result of SP1 phosphorylation. Thus, altered Cse promoter activity associated with SP1 phosphorylation might be related to other transcription factors, whose activity has been modified via the phosphorylation of SP1.

In conclusion, we report a novel transcriptional mechanism of glucose-induced downregulation of CSE in which SP1 phosphorylation by p38 MAPK acts as one molecular link between glucose level and CSE production as outlined

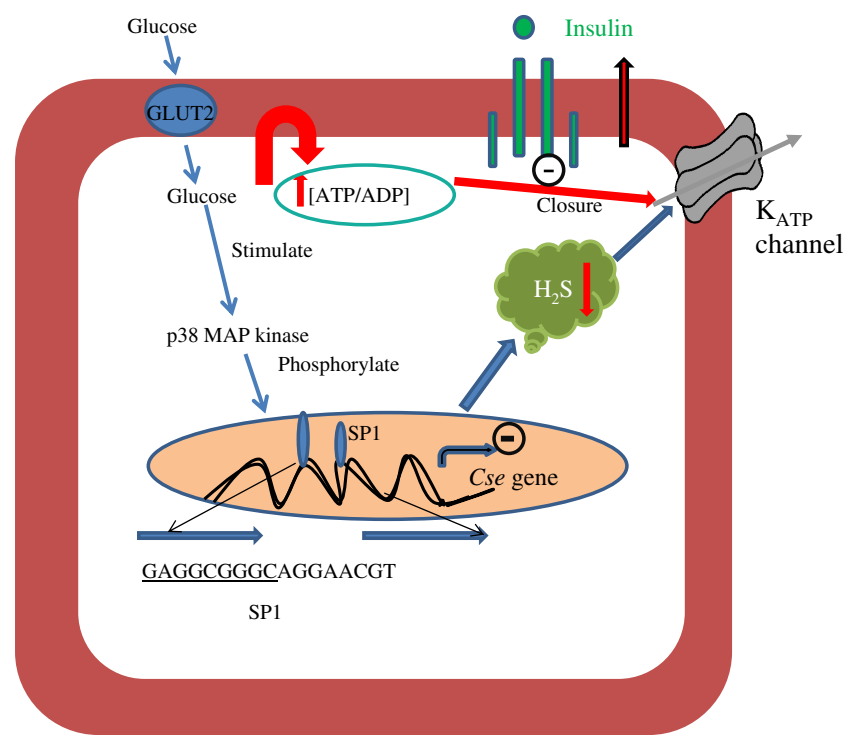

Fig. 8 Schematic signal transduction pathways underlying glucoserepressed CSE production 
in Fig. 8. A delicate interplay between glucose level and $\mathrm{CSE} / \mathrm{H}_{2} \mathrm{~S}$ in pancreatic beta cells would potentially underlie the regulation of glucose metabolism and insulin secretion under both physiological and pathological situations.

Acknowledgements This work is supported by a research grant from the Canadian Diabetes Association.

Duality of interest The authors declare that there is no duality of interest associated with this manuscript.

\section{References}

1. Wang R (2002) Two's company, three's a crowd: can $\mathrm{H}_{2} \mathrm{~S}$ be the third endogenous gaseous transmitter? FASEB J 16:17921798

2. Yang W, Yang G, Jia X, Wu L, Wang R (2005) Activation of $\mathrm{K}_{\text {ATP }}$ channels by $\mathrm{H}_{2} \mathrm{~S}$ in rat insulin-secreting cells and the underlying mechanisms. J Physiol 569:519-531

3. Wu L, Yang W, Jia X et al (2009) Pancreatic islet overproduction of $\mathrm{H}_{2} \mathrm{~S}$ and suppressed insulin release in Zucker diabetic rats. Lab Invest 89:59-67

4. Ali MY, Whiteman M, Low CM, Moore PK (2007) Hydrogen sulphide reduces insulin secretion from HIT-T15 cells by a $\mathrm{K}_{\text {ATP }}$ channel-dependent pathway. J Endocrinol 195:105-112

5. Waeber G, Thompson N, Nicod P, Bonny C (1996) Transcriptional activation of the GLUT2 gene by the IPF-1/ STF-1/IDX-1 homeobox factor. Mol Endocrinol 10:13271334

6. Brun T, Roche E, Kim KH, Prentki M (1993) Glucose regulates acetyl-CoA carboxylase gene expression in a pancreatic beta-cell line (INS-1). J Biol Chem 268:18905-18911

7. Allagnat F, Martin D, Condorelli DF, Waeber G, Haefliger JA (2005) Glucose represses connexin36 in insulin-secreting cells. J Cell Sci 118:5335-5344

8. Zhao W, Zhang J, Lu Y, Wang R (2001) The vasorelaxant effect of $\mathrm{H}_{2} \mathrm{~S}$ as a novel endogenous gaseous $\mathrm{K}_{\text {ATP }}$ channel opener. EMBO J 20:6008-6016

9. Cheng Y, Ndisang JF, Tang G, Cao K, Wang R (2004) Hydrogen sulfide-induced relaxation of resistance mesenteric artery beds of rats. Am J Physiol 287:H2316-H2323

10. Yang $\mathrm{G}$, Wu L, Jiang B et al (2008) $\mathrm{H}_{2} \mathrm{~S}$ as a physiologic vasorelaxant: hypertension in mice with deletion of cystathionine gamma-lyase. Science 322:587-590

11. Yang $\mathrm{G}$, Yang $\mathrm{W}, \mathrm{Wu} \mathrm{L}$, Wang $\mathrm{R}$ (2007) $\mathrm{H}_{2} \mathrm{~S}$, endoplasmic reticulum stress, and apoptosis of insulin-secreting beta cells. J Biol Chem 282:16567-16576

12. Yang G, Sun X, Wang R (2004) Hydrogen sulfide-induced apoptosis of human aorta smooth muscle cells via the activation of mitogen-activated protein kinases and caspase-3. FASEB J 18:1782-1784

13. Ishii I, Akahoshi N, Yu X et al (2004) Murine cystathionine $\gamma$ lyase: complete cDNA and genomic sequences, promoter activity, tissue distribution and developmental expression. Biochem J 381:113-123

14. Kaneko Y, Kimura Y, Kimura H, Niki I (2006) L-cysteine inhibits insulin release from the pancreatic $\beta$-cell: possible involvement of metabolic production of hydrogen sulfide, a novel gasotransmitter. Diabetes 55:1391-1397

15. Yusuf M, Kwong-Huat BT, Hsu A, Whiteman M, Bhatia M, Moore PK (2005) Streptozotocin-induced diabetes in the rat is associated with enhanced tissue hydrogen sulfide biosynthesis. Biochem Biophys Res Commun 333:1146-1152
16. Chang T, Untereiner A, Liu J, Wu L (2010) Interaction of methylglyoxal and hydrogen sulfide in rat vascular smooth muscle cells. Antioxid Redox Signal 12:1093-1100

17. Feng X, Chen Y, Zhao J, Tang C, Jiang Z, Geng B (2009) Hydrogen sulfide from adipose tissue is a novel insulin resistance regulator. Biochem Biophys Res Commun 38:153-159

18. Schuit F, Flamez D, De Vos A, Pipeleers D (2002) Glucoseregulated gene expression maintaining the glucose-responsive state of $\beta$-cells. Diabetes 51(Suppl 3):S326-S332

19. Roduit R, Morin J, Massé F et al (2000) Glucose down-regulates the expression of the peroxisome proliferator-activated receptoralpha gene in the pancreatic beta-cell. J Biol Chem 275:3579935806

20. Moritz W, Leech CA, Ferrer J, Habener JF (2001) Regulated expression of adenosine triphosphate-sensitive potassium channel subunits in pancreatic beta-cells. Endocrinology 142:129138

21. Vanderford NL, Andrali SS, Ozcan S (2007) Glucose induces MafA expression in pancreatic beta cell lines via the hexosamine biosynthetic pathway. J Biol Chem 282:1577-1584

22. Girad J, Ferre P, Foufelle F (1997) Mechanisms by which carbohydrates regulate expression of genes for glycolytic and lipogenic enzymes. Annu Rev Nutr 17:325-352

23. Gagliardino JJ, Martin JM (1966) Studies on the mechanism of insulin release. Metabolism 15:1068-1075

24. Kipnis DM, Cori CF (1959) Studies of tissue permeability. V. The penetration and phosphorylation of 2-deoxyglucose in the rat diaphragm. J Biol Chem 234:171-177

25. Nakada HI, Wick AN (1956) The effect of 2-deoxyglucose on the metabolism of glucose, fructose, and galactose by rat diaphragm. J Biol Chem 222:671-676

26. Landau BR, Ship AG, Levine HJ (1958) Action of insulin on distribution of glucose analogs in eviscerated-nephrectomized dogs. Am J Physiol 193:461-465

27. Wick AN, Drury DR, Nakada HI, Wolfe JB (1957) Localization of the primary metabolic block produced by 2-deoxyglucose. J Biol Chem 224:963-969

28. Lu Y, O'Dowd BF, Orrego H, Israel Y (1992) Cloning and nucleotide sequence of human liver cDNA encoding for cystathionine gamma-lyase. Biochem Biophys Res Commun 189:749758

29. Blume SW, Snyder RC, Ray R, Thomas S, Koller CA, Miller DM (1991) Mithramycin inhibits Sp1 binding and selectively inhibits transcriptional activity of the dihydrofolate reductase gene in vitro and in vivo. $\mathrm{J}$ Clin Invest 88:1613-1621

30. Li T, Bai L, Li J, Igarashi S, Ghishan FK (2008) Sp1 is required for glucose-induced transcriptional regulation of mouse vesicular glutamate transporter 2 gene. Gastroenterology 134:1994-2003

31. Schäfer D, Hamm-Künzelmann B, Brand K (1997) Glucose regulates the promoter activity of aldolase $\mathrm{A}$ and pyruvate kinase M2 via dephosphorylation of Sp1. FEBS Lett 417:325328

32. Rohlff C, Ahmad S, Borellini F, Lei J, Glazer RI (1997) Modulation of transcription factor $\mathrm{Sp} 1$ by cAMP-dependent protein kinase. J Biol Chem 272:21137-21141

33. Merchant JL, Du M, Todisco A (1999) Sp1 phosphorylation by Erk 2 stimulates DNA binding. Biochem Biophys Res Commun 254:454-461

34. Lam JK, Matsubara S, Mihara K, Zheng XL, Mooradian AD, Wong NC (2003) Insulin induction of apolipoprotein AI, role of Sp1. Biochemistry 42:2680-2690

35. Ge Y, Jensen T, Matherly LH, Taub JW (2003) Transcriptional regulation of the cystathionine-beta-synthase gene in Down syndrome and non-Down syndrome megakaryocytic leukemia cell lines. Blood 101:1551-1557 
36. Ko JL, Liu HC, Loh HH (2003) Role of an AP-2-like element in transcriptional regulation of mouse micro-opioid receptor gene. Brain Res Mol Brain Res 112:153-162

37. Chu S, Cockrell CA, Ferro TJ (2003) Expression of alpha-ENaC2 is dependent on an upstream $\mathrm{Sp} 1$ binding motif and is modulated by protein phosphatase 1 in lung epithelial cells. Biochem Biophys Res Commun 303:1159-1168

38. Daniel S, Zhang S, DePaoli-Roach AA, Kim KH (1996) Dephosphorylation of Sp1 by protein phosphatase 1 is involved in the glucose-mediated activation of the acetyl-CoA carboxylase gene. J Biol Chem 271:14692-14697

39. Samson SL, Wong NC (2002) Role of Sp1 in insulin regulation of gene expression. J Mol Endocrinol 29:265-279

40. Frodin M, Sekine N, Roche E et al (1995) Glucose, other secretagogues, and nerve growth factor stimulate mitogen- activated protein kinase in the insulin-secreting beta cell line, INS-1. J Biol Chem 270:7882-7889

41. Khoo S, Cobb MH (1997) Activation of mitogen-activating protein kinase by glucose is not required for insulin secretion. Proc Natl Acad Sci USA 94:5599-5604

42. Kaneko Y, Kimura T, Taniguchi S et al (2009) Glucose-induced production of hydrogen sulfide may protect the pancreatic betacells from apoptotic cell death by high glucose. FEBS Lett 583:377-382

43. Srinivasan S, Bernal-Mizrachi E, Ohsugi M, Permutt MA (2002) Glucose promotes pancreatic islet beta-cell survival through a PI 3-kinase/Akt-signaling pathway. Am J Physiol Endocrinol Metab 283:E784-E793

44. Chu S, Ferro TJ (2005) SP1: regulation of gene expression by phosphorylation. Gene 348:1-11 